\title{
ESPAÑA Y LA GUERRA DE LOS 6 DÍAS
}

\author{
por
}

\section{ISIDRO GONZÁLEZ GARCÍA}

Universidad Complutense de Madrid

RESUMEN: La reciente desclasificacion de parte de los archivos del Ministerio de Asuntos Exteriores nos permite ya abordar acontecimientos recientes de la vida internacional en los que estuvo involucrada la politica exterior española, muy especialmente, en el conflicto del Oriente Medio, como es el caso de la llamada Guerra de los 6 días (6-11/6/1967). Los intentos de mediación española en este conflicto comienzan ya en los origenes del mismo en el año 1948 y, vienen determinados por tres razones fundamentales: la primera la no existencia de relaciones con el Estado de Israel, la segunda los derechos bistóricos sobre los Santos Lugares y por ultimo las relaciones con los paises árabes. La orientación diplomática del entonces ministro de Asuntos Exteriores Fernando Castiella se mueve en el sentido de apoyar la causa árabe, a la veq que éstos como contrapartida apoyarian las tesis españolas sobre la internacionalización de Jerusalén y por otra parte los árabes a su vez recaban, además el apojo español con la finalidad de que España gestionase cerca de los paises bispanoamericanos el apoyo a la causa árabe en los Foros internacionales. La diplomacia española mantiene también contactos con el Vaticano buscando también su apoyo en el problema de Jerusalén. Sin embargo la diplomacia Vaticana adopta una postura maniquea, que consistía en defender de cara al exterior la internacionalización de los Santos Lugares, y en la realidad aceptando la situación de becho, es decir la ocupación de la ciudad por jordanos e israelies en perfecta sintonia con los intereses norteamericanos y británicos. La diplomacia española actua en los Foros internacionales movida por estas circuntanias, a las que bay que añadir las presiones norteamericanas sobre el gobierno de Madrid para que atenuase su posición proárabe $y$, como consecuencia de la misma, España protege a los intereses norteamericanos en muchos paises arabes, y logra una buena imagen exterior con la liberación de muchos judios que en aquellos momentos vivian en varios países árabes, especialmente en Egipto.

PALABRAS CLAVE: Guerra de los 6 dias. Relaciones internacionales. Conflicto ârabe-israeli. Países árabes. Israel.

ABSTRACT: The recent declassification of some of the Ministry of Foreign Affairs files allows us to tackle recent international events in which Spanish Foreign policy was involved, in particular with regard to aspects of the Middle East conflict, such as the so called 6 Day $\operatorname{Var}(6-11 / 6 / 1967)$.

Hipania, 1,IX/2, núm. 202 (1999) 693-718 
The Spanish efforts to mediate in this conflict date back to the origins of the war in 1948 and derive from three fundamental reasons: frstly the lack of relations with the State of Israel; secondly, the bistorical rights to the Holy Lands; and lastly the relationships with the Arab countries. The approach of the Minister of Foreign Affairs of that time - Fernando Castiella - was driven by the desire to support the Arab cause, at the same time as the Arab countries backed the Spanish thesis for the internationalisation of Jerusalem, witb the Arabs additionally requesting the support of the Spanish with the idea that Spain sbould obtain the support of the Hispano-American countries for the Arab cause within the various international forums.

The Spanish diplomatic corps similarly mainiained contacts with the ITatican in an effort to obtain their support with the Jerusalem problem. However, the Vatican diplomats adopted a somewbat two-faced posture, on the one band outwardly defending against the internationalisation of the Holy Lands, while on the otber band accepting the reality of the situation, that is to say the occupation of the city by Jordanians and Isratis in perfect barmony with the Amenican and British interests. Spanish diplomacy in the international arena was constrained by these influences, together with the additional pressure that was being applied by the Americans on the Madrid government to tone down their pro-Arab stance, and as a consequence of this protect the American interests in many of the Arab countries, and acbieved an excellent image with the rest of the world with the liberation of a large number of Jews who at that time lived in various Arab countries, particularly Egypt.

KIIY WORDS: Six Day War. International relations. Arab-Israeli Conflict. Arab Countries. Istrael.

\section{LOS ANTECEDENTES HISTÓRICOS DE LA INTERVENCIÓN ESPAÑOLA EN EL CONFLICTO ÁRABE-ISRAELÍ}

La relación española con el conflicto árabe-israelí no es nueva y hunde sus raíces en los propios orígenes del mismo. En 1948, cuando, en cumplimiento de la resolución de la ONU de 29 de Noviembre de 1947 se acuerda la partición de Palestina en 2 estados uno árabe y otro judio, nace el estado de Israel y se produce sin solución de continuidad la primera Guerra árabe-israelí, ya entonces el gobierno del General Franco intentó una intervención en la zona ${ }^{1}$. A partir de este momento de una manera u otra el conflicto ha estado presente siempre en la política exterior española. Sobre tres aspectos gravitaba esta actuación. La primera sobre las complicadas relaciones con el estado de Israel, la

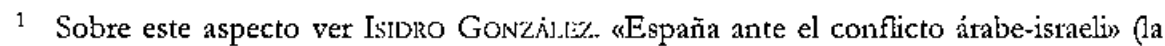
protección de los Santos Lugares, Historia $16 \mathrm{n}^{\circ} 189$. págs. 28-34. Y del mismo autor España, Israely los árabes (Inédito), págs. 32-64 sobre E/ conflicto de Oriente Medio. Para una visión general ver Jose U. Martinez CarRI:RAs. El Mundo Arabe e Istael, Madrid 1991. David Sol.Ar, El conflicto de Oriente Medio. Barcelona, 1975. Solomo-Benasu, Historia del Estado de Israel, Madrid 1981. I. Herzog, Las Guerras árabe-israeties. Jerusalén, 1987.

Hippomia, LIX/2, núm. 202 (1999) 693-718 
segunda la relación histórica de España con los Santos Lugares ${ }^{2}$ y por último su vinculación a los países árabes. En el primer aspecto hay que remarcar que ambos países estaban condicionados en aquellos momentos por unas circunstancias excepcionales que hacían muy dificil esta relación. EI régimen de Franco que soportaba un atosigante aislamiento internacional buscaba el reconocimiento del estado hebreo, por el respaldado que le suponía en aquellas circunstancias, esgrimiendo como argumento la salvación de miles de judios durante el Holocausto. El Estado de Israel no sólo negó este reconocimiento sino que ni siquiera comunicó al gobierno español la constitución como tal estado, alegando que España había sido un aliado activo de los régimenes que causaron 6 millones de muertos al pueblo judío, en clara alusión al nazismo alemán. Esta situación provocó una reacción hostil en el gobierno español y el propio general Franco se sintió herido. Se inicia así, lo que el primer embajador de Istael en España Samuel Hadas ha llamado «una relacion asimétrica», es decir cuando a uno le interesa esta relación al otro le molesta, por la circunstancia del momento y viceversa, como más tarde ocurrió cuando Israel intenta los acercamientos a España ${ }^{3}$.

En el segundo aspecto los derechos históricos de España sobre la protección de los Santos Lugares proceden ya del siglo XVIII, y desde entonces el gobierno español mantuvo un protagonismo a través de la llamada Obra Pía, canalizándolo a través del Consulado de Jerusalén. Al estallido del conflicto esta situación se va proyectar como un mecanismo de penetración española en la zona, que ya estará presente durante todo el tiempo que durará el mismo y condicionará su posición en los Foros internacionales, buscando los apoyos de los países latinoamericanos con la finalidad de hacer de Jerusalén una ciudad internacional y así poder intervenir en el gobierno de la misma ${ }^{4}$.

2 Sobre la relación de España con los Santos Lugares ver CONDS DE CAMro RrY, Historia diplomática de Españay los Santos Lugares (1770-1980), Madrid 1982 y CONDE DE BALLOBAR, Diario de Jerusalen 1914-1919, Madrid, 1996. Edición e introducción a cargo de Eduardo MANZANo. Sobre la historia de la Obra Pia ver P. Ej $\Lambda \mathrm{N}$, Hippanidad y Judaismo en Tierra Santa. Actuación diplomática. Edición Ministerio A. Exteriores, Madrid, 1913 y del mismo autor Documentos relativos a La Obra Pía de los Santos Lugares en Palestina, Santiago, 1939 y R. Orivi: HirnÁndez, «El Consulado español en Tierra Santa (1913-1923)m. Tesis Doctoral, Universidad Autónoma, Madrid, 1992.

3 Sobre las relaciones hispano-ismaelies ver Ranan Rein: Franco Israely los judios, Madrid, 1996. Del mismo autor, «La negativa israelí: las relaciones entre España e Israel en 1948-49\%. Hispania, 172, Madrid, 1989 págs. 659-688. Isıro Gonzàl.zz, Espaĩa, Israel y los árabes (Inédito). SAMUEl HADAS, «España e Israel 500 años después» en Rev Politica Exterior n 30, Vol VI págs. 191-206, Madrid, 1993. HAIs AVNI, «Los judios y Franco en 1949 un encuentro desmitificado", publicado en Encuentros en Sefarad, Ciudad Real, 1987, págs. 393-415; y en la misma publicación, J. Carlos PEREIra y Fernando G. SAN'z, «Relaciones entre España e Israel. Los condicionantes para un entendimiento", págs. 369-393. J. ANronto LisBona. El retorno a Sefarad, Madrid 1993, págs. 278291 y A. Marquina y G. Ospins, España y los judios sigho XX, Madrid, 1987 págs. 314-334.

4 Isjdro GONZÁLLZZ, «España ante el conflicto árabe israelí y la protección de los Santos Lugares en el año 1948», Historia 16, n 189 , Madrid, 1992, págs. 28-34. Del mismo. España, Israely los árabes, págs. 28-67.

Hi.puniu, LIX/2, núm. 202 (1999) 693-718 
En cuanto al tercer aspecto, muy importante, suponen los países árabes el primer soporte en el que se apoyó el régimen de Franco para salir de su aislamiento, que sin embargo también tenía como contrapartida sus hipotecas, como eran que España hiciese valer sus buenos oficios cerca de los países latinoamericanos, con la finalidad de que estos apoyasen la causa árabe en los Foros internacionales, mientras que estos apoyarian las tesis españolas sobre Jerusalén, habiendo que añadir además que esta amistad hispano-átabe suponía un mecanismo de amortiguamiento del nacionalismo del Norte de Africa, donde España tenía muchos intereses, aspecto muy bien estudiado, en el libro de Dolores Algora Weber ${ }^{5}$.

En medio de esta situación el entonces ministro de Asuntos Exteriores español Alberto Martín Artajo maniobra orquestando una campaña contra Pablo Azcárate, Presidente de la Comisión de pacificación de Palestina. La razón de la misma estaba fundamentada en el hecho de que el diplomático español era un exiliado republicano y podría dar un sesgo contrario al régimen del general Franco, especialmente cerca de los países árabes. La campaña estaba orquestada en el sentido de que Azcátate no tepresentaba la línea diplomática del gobierno español, y ser un elemento proclive a las tesis israelíes 6 .

La evolución de los acontecimientos posteriores tanto en el conflicto del Oriente Medio, como en la propia política exterior española van a invertir en cierta medida la situación del gobierno de Franco ante el conflicto. Así pues en 1953 se firman los acuerdos con EEUU y dos años más tarde España ingresa en la ONU como miembro de pleno derecho. Israel intenta los acercamientos a España, a los que el gobierno español se niega, es decir, la asimetría de la que habla Hadas se invierte ${ }^{7}$. Sin embargo lentamente se va creando en el seno del gobierno de Franco una corriente de acercamiento al estado hebreo, principalmente entre los diplomáticos españoles que se encuentran tanto en EEUU como en la ONU.

Representan esta tendencia entre otros José María Areliza, embajador en Washington y J. Félix de Lequerica representante en La ONU. Las razones que aducían eran el poder e influencia que ejercían las comunidades judías nortea-

5 Dolores ALCORA Weisis, Las Relaciones Hispano - árabes durante el régimen de Franco (La ruptura del aislamiento internacional), Madrid, 1996, págs. 81-191. Supone este libro el primer estudio exhaustivo sobre la consolidación de las relaciones con el Mundo Arabe. Isidro GonzALLZZ, España, Israel y los árabes, págs. 73-105. Jorge DEZCALLAR, «España el problema palestino» Rev Politica Exterior, Vol. V, n 19 , págs 8-21. Para una visión general de las relaciones hispanoárabes, especialmente en el N. de Africa, V. Morslres LEzCANo, España y el Norte de Africa. El protectorado de Marruecos, Madrid, 1984, y Fernando Morín, Una politica Exterior para España, Madrid, 1980, paigs. 172-215.

"Isidro GonZÁLEZ, «Pablo Azcárate perseguido por Franco», Historia 16, no 220, págs. 2128. Es muy interesante sobre la actuación de este diplomático en el conflicto Oriente- Medio, ver Pablo Azcárates, Misión en Palestina, Madrid, 1968, y también su diario, cajas 1 y 2, así como su Archivo de 1948 a 1952.

7 Isidro GonzÁ...z, España, Israely los árabes, pág. 208-257, y RMANAN Ruin, Franco, Israely los jutios, paigs. 278-310.

Hitpunia, J.JX/2, núm. 202 (1999) 693-718 
mericanas sobre el Gobierno de Washington y que afectaría a la posición española en el conflicto ${ }^{8}$. Aún más, se intentó en los prolegómenos del estallido de la crisis de Suez que España interviniese como mediadora en el conflicto, que ya se barruntaba.

Este grupo de diplomáticos es proclive a un acercamiento a Israel y recomiendan a Artajo que no deseche del todo estas ofertas por la coyuntura internacional del momento y los beneficios que nos podría reportar, y así lo expresa el propio Areliza a Artajo, que le transmite la posición de las comunidades judias norteamericanas. «Hace unos dias fui visitado por dos de estos importantes elementos del mundo bebreo norteamericano. Sin mas preámbulos entraron en materia que apuntaba nada menos que a la posibilidad de que a nuestro jefe de Estado se le nombrase mediador en la disputa. Argumentaban mis visitantes en el sentido de que, siendo el uinico de los gobiernos de Occidente que goza de una autoridad moral y prestigio indiscutible en el mundo árabe, nadie lo babria de considerar sospechoso por ese lado, mientras que los israelitas lo respetan cada día más por su firme posición anticomunista. Dado que el apoyo al mundo árabe procede en estos momentos del campo soniético, nadie mejor que él para intervenir a fin de evitar un conflicto en el Mediterráneo y desbacer la maniobra musa en el Medio Orientes". La estrategia era clara y Artajo no dehecha la idea siguiendo las sugerencias de Areilza y buscando como contrapartida una mayor ayuda norteamericana. Los países árabes sin embargo rechazan de plano esta idea al considerarla una maniobra israelí vía Washington y como consecuencia, los intentos de mediación española no se materializan. Aún así, sigue aumentando esta corriente de opinión en muchos políticos españoles en torno a una medición en el conflicto del Oriente Medio y a un acercamiento al estado de Israel. Esta situación llega a crear momentos de máxima tensión interna en el gobierno de Franco, cuando ocupa la cartera de Exteriores Fernando María Castiella, que reafirma aún más su posición proátabe, lo que genera un enfrentamiento con Lequerica, que junto a otros diplomáticos mantenían contactos con destacados políticos israelíes como Abba Ebban, y Golda Meir tratando de conseguir un acercamiento entre España e Istael "'. Esta tónica con altos y bajos se mantendrá hasta el estallido del conflicto que es objeto de este estudio.

\section{LA POLÍTICA EXTERIOR ESPAÑOLA EN LOS ALEDAÑOS DEL CONFLICTO}

Dentro del ya largo y endémico conflicto árabe-israelí la denominada Guerra de los 6 días, fue quizá la más espectacular y la que más incidencia tuvo en los acontecimientos posteriores. El conflicto se inicia en el 5 de Junio de 1967

\footnotetext{
8 Isidro GonzÁ._zz, España, Israely los árabes, pág. 218 y ss y RAANAN Rein, Franco, Israel y los jwdios, págs. 282-282.

9 Isidro GonzÁlbz, «La Mediación española en la crisis de Suez», en Historia de las relaciones Internacionales (Una visión desde España), Madrid, 1996 págs. 401-416.

10 Ranan Rrin, Op. cit., págs. 282-284; Isidro Gon/,íl.z, «Un Lobby Pro-istaelí en el Gobiemo de Franco. El enfrentamiento Lequerica-Castiellay, Ha. 16, n. ${ }^{\circ}$ 268, págs. 14-21, Madrid, 1998. A Marquina y G. Osisina, España y los judios, pag 283 y ss.
} 
al sentirse Israel amenazado por la actitud beligetante de algunos países árabes, especialmente Egipto y Siria. La aviación israelí lanzó un ataque sorpresa sobre los aeropuertos primero egipcios y más tarde sirios, jordanos, iraqués, con lo cual se convirtió en dueño absoluto del espacio aéreo. Tan sólo 6 días más tarde los países beligerantes árabes pidieron la paz. (11/6/67).

Esta guerra que tuvo este desenlace tan rápido tuvo una incidencia muy importante en cuanto a lo que se podría liamat desestabilización territorial de la zona. Israel ocupó el desierto del Sinaí a Egipto. La Cisjordania, y la meseta del Golán a Siria.

Tras intensas y laboriosas reuniones, la $\mathrm{ONU}$ aprobó el 22 de noviembre la Resolución 242, por medio de la cual se instaba a la retirada de las fuerzas armadas israelíes de los territorios ocupados y además se afirmaba el derecho, que tienen todos los estados de la zona a vivir dentro de unas fronteras seguras y al reconocimiento de su soberanía e integridad territorial. Se mencionaba además la necesidad de resolver el problema de los refugiados palestinos y la libertad de navegación en aguas internacionales.

\section{¿Cuál fue la posición española en este conflicto?}

A comienzos de 1967, y hasta el desencadenamiento de la Guerra, la tensión va in crescendo en la zona. El consul español en Jerusalén infoma de una manera periódica sobre el asunto, especialmente sobre los Santos Lugares, cuestión que volvía a emerger con toda su candencia involuctado en un sinfin de problemas, cuyas variables más importantes estaban vinculadas a las propias relaciones entre los árabes muy especialmente entre Jordania y Egipto, debido a la presión que ejercía este último sobre el teino hachemita en el sentido de autorizar un consulado egipcio en la zona jordana de Jerusalén.

Por otra parte, con respecto a España, se volvía a plantear la tradicional protección de las potencias católicas a los Santos Lugares, de las que España no queria desengancharse, mientras que a su vez Israel quería convertir a Jerusalén en la capital del Estado.

Los primeros síntomas comienzan ya a notarse en Diciembre de $1966 . \mathrm{El}$ Cónsul español informa a Madrid de las maniobras árabes en torno a la presión sobre los cónsules extranjeros en la zona jordana de Jerusalén. La ciudad se había llenado de súbito de cónsules árabes que consideraban al resto de cónsules especialmente a los de las potencias católicas como a extranjeros, porque defendían el llamado Corpus separatum o ciudad internacional. La presión, sin duda, iba encaminada a crear dificultades a estos países obligándoles a abandonar, y por otro lado intentar crear una zona árabe ".

Es evidente que estamos en el comienzo de una presión sostenida, protagonizada por Siria y Egipto, contra la presencia occidental en la zona.

11 AMAE Leg. R. 8543/12 y J.R. Riın, ob. cit., pág. 278-310. J. Antonio Lisions, ab. cit, pág. 191-212. MnRQuins, op. cit., pág. 306-307.

Hihpania, LIX/2, núm. 202 (1999) 693-718 
La presión que el resto de los países árabes realizan ya abiertamentc sobre Jordania, para que a su vez la ejerciese sobre los cónsules de su zona son ya evidentes. El embajador español en Amman recibe un comunicado del Gobierno jordano en este sentido. Al depender el Consulado español de la embajada en Amman se prohibía expresamente que cualquier diplomático español destinado a la embajada en Jordania fuese enviado al consulado de Jerusalén. «Tiene la honra de rogarles - dice la nota- que tengan la atención de comunicar al Ministerio previamente sobre las personas que se incorporasen a la embajada en Amman y posteriormente destinados al Consulado de Jerusalen» ${ }^{12}$.

Este control por parte de Jordania, planteaba problemas al Gobierno español, que aducía precisamente su amistad con los países árabes para mantener una presencia activa en Jerusalén.

Esta situación provocó la reacción muy hostil especialmente de los embajadores británico y norteamericano que se entrevistan con el primer ministro jordano Wasfi Teel, advirtiéndole de la gravedaed de la situación. EI cónsul español en Jerusalén comunica al Gobiemo de Madrid, que el Gobiemo jordano ante tales presiones no insistiría sobre el cambio del Statu Quo de los cónsules extranjeros, dejando entrever que era presionado por el resto de los países de la liga árabe de acuerdo con sus propios intereses y poniendo sobre aviso al Gobierno español de que en el próximo viaje a España dirigentes de la liga árabe lo plantearían al Gobiemo de Madrid ${ }^{13}$.

¿Cuál debía de ser la posición española ante el delicado asunto? El Cónsul general de España en Jerusalén, Alberto Pascual Villar, en un extenso y reservado informe pone al corriente al ministro Castiella ${ }^{14}$.

Resume así la cuestión respecto a España. "Los árabes tratan de acabar con el Statu Quo de Jerusalén como medio de aislar a Israel y con el fin también de privarle de la recepción de más de 300.000 turistas que debian de acceder por la parte jordana. Frente al irredentismo de los judios que siempre ban proclamado que Jerusalén es la capital bistónica del judaísmo, se alya la casi seguridad de que los árabes no permitirán que los judios lleven a cabo sus propósitos y asi podran mantener la ciudad vieja y los beneficios del turismo cristiano. Por lo tanto lo que ni árabes ni judios desean previamente, es la internacionalización de Jerusalén de acuerdo con lo que resolvió en su día la ONU, y ba proclamado la Santa Sede por boca de su S. Pio XII y en estos dias Pablo VI\%. En este interesante informe, el Cónsul español comunica los contactos mantenidos con los demás cónsules de Jerusalén, excepto Gran Bretaña y EEUU y en síntesis han coincidido que: " $1^{\circ}$ la medida se trata de una finta encaminada a conocer la reacción de Gran Bretaña y EEUU; $2^{\circ}$ que el gobierno jordano no convocó a los países católicos al estar seguro de su negativa; $3^{\circ}$ que la iniciativa partió de la liga árabe especialmente de Egipto y Siria que toman la iniciativa en el sentido de distanciar a los cónsules árabes de los llamados extranjeros y a su vez Jordania podria permitirse este

12 Ibidem. Informe reservado 17.

13 Ibidem. Informe reservado 43, 24/1/67.

14 Ibidem. informe 57 confidencial de Pascual Villar a Castiella 31/1/67. 
gesto en prueba de solidaridad con los árabes; $4^{\circ}$ el Cónsul informa a Madrid de la preocupación del Vaticano sobre esta cuestión en entrevista mantenida con el Delegado Apostólico. En este ambiente reinaba un gran pesimismo entre los cónsules extranjeros, el propio cónsul de Italia afirmaba que todo iba más deprisa de lo que él mismo suponía. Por su parte, el cónsul norteamericano se refirió a la presión que Israel ejercía sobre su Gobierno para trasladar la embajada a Jerusalén. «Personalmente -escribe el cónsul- creo que se está llegando al momento en el que de un modo más o menos claro y decidido se intente por todos los procedimientos posibles atacar al status de los cónsules de Jerusalény.

«Puede que esta vez se trate de un amago, pero es evidente, que seguirán otros muchos. Creo también en el caso de España que se intentará conseguir como una prueba más de amistad con los países árabes, que limitemos nuestra actividad en la zona árabe de Jerusalén». Advierte a Castiella que ante la inminente visita a España de una comisión de la liga árabe sería ocasión propicia para que nos hicieran esa propuesta. "Conoce demasiado bien V.E. las consecuencias que esto podría tener y le atrevo a sugerir, escribe el Cónsul español, que dado el modo y el momento que V.E. estime conveniente y si tal es la opinión de V.E. se advierta a los países árabes amigos y especialrnente a Jordania que el mantenimiento del actual Statu Quo es de vital irnportancia para los países cristianos y especialmente para España que sólo dispone de ese medio y de la amistad con los países árabes» ${ }^{15}$.

¿Cuál fué la posición ante esta delicada situación del Gobierno español?. Se generó una intensa actividad diplomática, especialmente en torno a las relaciones con sus amigos árabes que había orientado su política en la línea más delicada para España, muy especialmente con Jordania que le creaba dificultades a la diplomacia española en el Oriente Medio y sobre todo en torno a los Santos Lugares. El 15 de febrero de ese año los embajadores de España en Amman y el Cónsul en Jerusalén reciben instrucciones muy reservadas sobre la conducta a seguir. "Cúmpleme manifestarle, escribe el Dr. General de Política Exterior, realizar todos los esfuerzos viables, en la forma que estime más oportuna y eficaz dadas las circunstancias locales, para tratar de mantener la cohesión y colegialidad del cuerpo consular en Jerusalén, como símbolo de la unicidad de la Ciudad Santa para que sean respetados los privilegios e inmunidades que desde siempre le han sido reconocidos en atención a los intereses espirituales y materiales, cuya conservación tiene el deber de preservar y que están en estrecha relación con las resoluciones que dictó la ONU sobre Jerusalén y su zona, que configuran como Corpus Separatum internacional. Ruego estrecha colaboración con embajada en Ammany.

El mismo día se envían instrucciones al embajador en Amman que son bien elocuentes, ignorando acuse de recibo de información por parte del Gobierno jordano: "Cúmpleme manifestatle para su sólo conocimiento y orientación y

15 Ibidam, pág. 5-6

Hispania, I.IX/2, núm. 202 (1929) 693-718 
sin que por ello deba dar lugar a comunicación escrita alguna, que no siendo normal en la praxis internacional ni estando concorde con las excelentes relaciones que España mantiene con ese reino, la exigencia de una comunicación previa para la incorporación de funcionarios diplomáticos a una embajada debidamente acreditada, debe V.E. dar por no recibida la antes aludida nota verbal...». En cuanto a su política sobre Jerusalén, las instrucciones son bien claras. «Le recuerdo a Ud. a título estrictamente orientador que mientras no surjan nuevas circunstancias a ponderar, España debe seguir considerando el enclave de la Ciudad Santa como un Corpus Separatums. Sin embargo las instrucciones apuntan también a evitar el crear roces inútiles y siempre que lo permitan las necesidades del servicio, no destacar a Jerusalén personal diplomático que haya estado en Amman ${ }^{16}$.

La actividad es muy intensa, al día siguiente el propio Casteilla nuevamente se dirige al embajador en Amman, Ramón M. ${ }^{a}$ Sobredo. Ante la inminente convocatoria del primer ministro jordano a los embajadores de EEUU y Gran Bretaña anunciándoles la intención de acabar con la peculiar situación de los cónsules en Jerusalén. «Dadas las implicaciones políticas —escribe Castiella al embajador - por afectar no solamente a los intereses españoles en la zona de Jerusalén sino también a toda la situación de Palestina, agradecería informara a este Departamento sobre la veracidad o falta de fundamento de la noticia... en función de la delicadeza del asunto encarezco la mayor reserva. Se dan instrucciones al Cónsul de Jerusalén para que se ponga en contacto con Ud, ${ }^{17}$.

Esta era la situación de espera e interés que rondaba entonces el Gobierno español sobre el asunto. El 2 de Marzo en un extenso informe confidencial y muy reservado el embajador en Amman advierte al Gobierno de Madrid de la situación.

El primer contratiempo surge cuando el propio embajador tiene que realizar la gestión casi a contrapelo a través del simple planteamiento al Gobierno jordano de la internacionalización de los Santos Lugares, cuestión a la que era opuesto el Gobierno del Rey Hussein, lo que provocaría una reacción contra España que, sin duda, se quería evitar para no indisponerse con el bloque árabe por el que España había apostado. "Conviene evitar -escribe el embajador a Castiella- cualquier reacción hóstil, si no se está seguro del apoyo a nuestra postura de Gran Bretaña y sobre todo de EEUU cuya influencia es decisiva en este paiss) ${ }^{18}$.

Este era pues el quid de la cuestión.

La estrategia española consistió ante esta eventualidad en canalizar la protesta hacia el Estado de Israel exclusivamente basando su acusación en querer hacer a Jerusalén capital del estado y así impedir la internacionalización, así como, en una aproximación tanto a británicos y norteamericanos para mantener el Status Quo actual como mal menor.

16 Ibidem, cifr 20 instrucciones para el embajador en Amman.

17 Ibidem, cifr 23 de Castiella a Ramón $\mathrm{M}^{\text {a }}$ Sobredo.

18 Ibidem. Informe reservado 91. 
El Cónsul español en Jerusalén intensifica los contactos con las autoridades árabes de Jerusalén jugando siempre la baza de su apoyo y mantener siempre intactas sus aspiraciones sobre los Santos Lugares. Sin embatgo aparecía otra vertiente del problema que se conventía en recurtente de vez en cuando, como eta la posición real del Vaticano ante el asunto y que era un referente de actuación para la diplomacia española. El 15 de marzo Castiella cursa instrucciones al embajador en el Vaticano Antonio Garrigues, y al de Italia, país que también estaba en perfecta sintonía con la actuación vaticana. «Agradecería a VE realizara sondeos reservados cerca de ese Gobierno y de los circulos vaticanos para informar a este Departamento sobre la actitud de la Santa Sede ante un posible y futuro cambio del actual status en la zona de Jerusalén y de los Santos Lugares de Palestina, actitud que es imprescindible conocer para fijar nuestra posturas ${ }^{19}$.

Castiella sigue con especial interés la evolución de la situación del problema pendiente de estos dos polos: la posición del Gobierno jordano en sus relaciones con EEUU y Gran Bretaña y la posición vaticana. A tenor de esta evolución se define su estrategia. El 4 de abril de nuevo el embajador en Amman precisaba el alcance de las medidas a tomar, a la vista de la situación en aquellos momentos. Así pues, el embajador refiriéndose al telegrama enviado por el Gobierno jordano sobre el no trasvase de diplomáticos españoles al consulado de Jerusalén, sigue las intrucciones de Madrid de no datlo por recibido. Sin embargo el Gobierno jordano envía un nuevo telegrama matizando el anterior, sustitayendo la frase comunicar previamente por la de informarse sobre los nueyos diplamáticos llegados. Todo lo cual confirma el efecto producido por la presión angloamericana sobre Hussein ${ }^{20}$. Cuestión que le había creado una cierta humillación ante el resto de las partes árabes, especialmente Siria y Egipto. Además de aumentar la tensión con los diplomáticos occidentales de Jerusalén. Por este lado la politica de Castiella mantiene vivas las aspiraciones debido a su propia conveniencia derivada de la posición occidental que paraba a Jordania y además las noticias que le llegaban del otro lado, tanto del Vaticano como del Gobierno italiano, le tranquilizaban. El 7 de abril, el embajador, español en Roma advierte a Artajo que tanto el Vaticano como Italia, no se oponen totalmente a la propuesta anglo-norteamericana.

Quedando el proyecto jordano como una declaración para uso interno átabe, que no de un proyecto serio. Sin embargo, se estima que Israel está aprovechándose de está situación y está trasladando a muchas embajadas de Tel Aviv a Jerusalén, así como va a realizar un desfile militar en la misma ciudad como conmemoración del aniversario del Estado. La confirmación le es trasmitida al propio Castiella el 7 de abril por el propio embajador español en Roma a raíz de la entrevista del presidente Fanfani y Hussein cuando éste último comunica la dificil situación en que se encontraba presionado de una parte por el extremismo árabe y por otra teniendo que hacer frente a las provocaciones judías ${ }^{21}$.

19) Ibidem, cifr 29 de Castiella a Garrigues.

20) Ibidem, paig 2.

21 Ibidem, desp. reservado 488 del embajador en Roma a Castiella.

Hi.paniu, LIX/2, num. 202 (1999) (19)3-718 
Toda la maquinaria desplegada por Nasser en torno a un inminente ataque a Israel y bajo la protección soviética alcanza en estas fechas su punto culminante. La diplomacia española sigue expectante la evolución, centrada sobre todo, en el problema de los Santos Lugares. Por un lado necesitaba el apoyo del Vaticano y los occidentales, especialmente EEUU, y por otro lado el árabe al que se había vinculado a través de los contactos permanentes que mantenía el Cónsul Alberto Pascual en Jerusatén.

Ya en el mes de mayo y en los aledaños de la Guerra de los 6 días nuevamente el Cónsul de España en Jerusatén pone al corriente al Gobierno de Madrid de la situación y de la posición que debía de adoptar el Gobierno español. Según el informe, los occidentates y especialmente EEUU realizan una doble política, una de cara al exterior, defendiendo la internacionalización especialmente en los foros internacionales, mientras que de hecho y paralelamente tratan de mantener un Statu Quo actuando sobre Jordania e Israel para que lo mantuviesen como un mal menor, puesto que sc garantizaba su acceso a los Santos Lugares, cuestión a su vez que contaba con el apoyo tácito del Gobierno de Fantani, en perfecta sintonía con el Vaticano como se desprendía de la actuación del propio Cónsul italiano en Jerusalén y del Delegado Apostólico quedando la posición española un tanto descolgada, lo mismo que las de los países católicos Bélgica y Francia.

La cuestión adquiere mayor grado de tensión cuando los propios países hispanoamericanos que siempre apoyaron al Gobierno español en la internacionalización de Jerusalén trasladan sus embajadas a esta ciudad a pesar del recordatorio que el propio cónsul español les hizo de los compromisos adquiridos con el Gobierno de Madrid ${ }^{22}$.

$\mathrm{El}$ hecho ya es un síntoma evidente de la influencia norteamericana sobre estos paises que habian dejado en un segundo plano la proposición española.

En esta situación, días más tarde, estalla el conflicto conocido como Guerra de los 6 días. La posición diplomática española está marcada por la situación que hemos descrito.

\section{ESPAÑA DURANTE EI CONFLICTO. ACTIVIDAD DIPLOMATICA}

La posición de la diplomacia del Gobierno español es un tanto ecléctica. Al mismo tiempo que apoya a los árabes no quiere hacer esta postura demasiado ostensible para no oponerse a la política norteamericana en el conflicto, que era pro-istaeli. Por otra parte, España intentó jugar como ya hizo en 1948-49 la baza de los paises hispanoamericanos en los Foros internacionales de cara a mantener su posible influencia en torno al problema de los Santos Lugares, lo que la hacía estar pendiente a su vez de la posición Vaticana, cuyo apoyo moral y diplomático era muy importante.

22 ANLE Lag. 8543/13. 
Este entresijo de intereses va a condicionar durante este tiempo una febril actividad diplomática dirigida fundamentalmente en estos frentes: $1^{\circ}$ hacia los países árabes, dándoles su respaldo, $2^{\circ}$ hacia los países hispanoamericanos con la finalidad de que apoyen la propuesta española de internacionalización de Jetusalén y de los Santos Lugares.

Este entramado se completaba con el frente diplomático vaticano con el que mantiene una intensa actividad buscando su apoyo también, al mismo tiempo que el de otros países con intereses análogos a los de España como Francia, Italia, y por último, las relaciones con el Gobierno norteamericano al que convenía no desairar ni magnificar la postura proárabe, debido a la dependencia que manteníamos de Washington o sobre todo a la influencia que las poderosas comunidades judías americanas ejercían sobre el Gobienno norteamericano. En este sentido quizás una de las mayores contrapartidas españolas fue protección de los intereses norteamericanos en los paises árabes (Egipto y Mauritania) y sobre todo la protección y evacuación de muchos judíos, especialmente sefarditas sobre todo en Egipto y el Líbano, muchos de los cuales fueron evacuados a España socorridos por centros de asistencia españoles y de las comunidades judias en Madrid y Barcelona.

Ante el inminente estallido del conflicto la diplomacia española empieza a tomar posiciones. El 1 de Junio el MAE elabora un extenso y pormenorizado informe sobre los efectos posibles del conflicto pero centrado sobre todo en la incidencia que tendría en los Santos Lugares y que afectaría a los intereses españoles así como a la orientación diplomática que habría que dar en cada caso.

En un memorandum que es enviado a las embajadas españolas se recordaba que Francia, so pretexto de proteger los Santos Lugares, en anteriores ocasiones ocupó Siria y el Líbano. Se enumeraba de una forma reiterada la lista de conventos e instituciones religiosas que debían de ser protegidas, muchos de las cuales se encontraban en zona de ocupación israelí.

La posición española se mantendría inalterable en cuanto a la situación del Corpus Separatum de Jerusalén ${ }^{23}$.

El embajador español en el Vaticano, Antonio Garrigues, sondea la posición vaticana ante el conflicto para aclarar su verdadera posición, la cual iba desde la internacionalización plena y total y ser opuesta a una intervención, hasta el mantenimiento de la actual situación de hecho y disfrazada de una ficción jurídica. La postura era ambigua, según el embajador, como lo demostraba el reciente viaje del Papa a los Santos Lugares, que ha sido interpretado por los actuales ocupantes como una confirmación de este última postura. Ante el inminente estallido del conflicto el cuerpo consular en Jerusalén, a iniciativa del Cónsul español, propone declarar a Jerusalén ciudad abierta. El embajador de Francia en Madrid comunica al Gobierno español que apoyatá con gran interés la propuesta del Cónsul español. El Gobierno español propugna ante este panorama tres posibles actuaciones: $1^{a}$ si Israel ocupase el que había sido sector

23 AMAE, Leg. R. 8543/13 memorandum del MAE 1/6/67.

Hi.pania, LIX/2, núm 202 (1999) 693-718 
jordano de la Ciudad Santa, en cuanto se hiciese efectivo el alto el fuego, Israel contaría con una baza importante en sus manos para ser jugada en sus negociaciones. $2^{\mathrm{a}}$ que convendria tener en cuenta que la incorporación simple y pura de la ciudad vieja al Estado de Istael crearía a éste problemas internos graves al exigir las religiones de rito ortodoxo un solar que ya ocupa la mezquita de Omar. $3^{a}$ no se descarta por ello la posibilidad de que Israel proponga la internacionalización vieja de Jerusalén, para permitir el acceso a los hebreos al muro de las Lamentaciones, considerado para ellos muy sagrado. Acceso previsto por el Armisticio con Jordania, pero que no ha sido permitido, y la última posibilidad el que se garantizase por las Naciones Unidas el acceso a los templos y lugares de oración ${ }^{24}$.

La diplomacia española toma iniciativas cerca de los países hispanoamericanos con la finalidad de buscar apoyo en la cuestión de los Santos Lugares, el 5 de junio el embajador español en la ONU, Manuel Aznar, comunica al Gobierno de Madrid que Argentina está dispuesta como miembro de la comisión del Consejo de Seguridad a tomar la iniciativa de paz e introducir en el discurso del día 6 la propuesta española de crear un Corpus Separatum en Jerusalén ${ }^{25}$. Ese mismo día se desarrolla una febril actividad, Castiella envía una circular a los embajadores españoles en Amman, El Cairo, Damasco, Bagdag, Beirut y Noua Chok, recomendando que en sus contactos con los gobiernos átabes les apoyen pero sobre todo tengan presente como arma política la cuestión de los refugiados de Palestina dejando bien claro su posición proárabe. «Nos mueve especialmente a este llamamiento nuestra amistad con los países árabes, a ellos unidos por un antiguo vínculo histórico, así como el natural interés que por su propia posición geográfica tienen todos los acontecimientos que afectan al área Mediterráneas. Castiella vuelve a hacer hincapié a los embajadores españoles en que reactiven sus gestiones sobre los árabes en el sentido de la protección diplomática de los Santos Lugares ${ }^{26}$.

Estas decisiones emanaban del propio Genetal Franco que ese mismo día 6 en un discurso en Tarragona confirmaba las directrices de Castiella que literalmente son las mismas que el propio ministro envía en circular a los embajadores ${ }^{27}$.

En pleno conflicto y también en plena actividad diplomática en la ONU, el embajador español en la Santa Sede, se entrevista el día 7 de junio con el subsecretario de estado Monseñor Felici, el cual le propone 4 puntos y que sería deseable que España asumiera: $1^{\circ}$, que los Santos Lugares entran en un peligro de consecuencias irreversibles, $2^{\circ}$ que se apliquen los acuerdos de la ONU de 1947 confirmados por los de 1948 y 1949 por los que Jerusalén y sus alrededores queden constituidos como un Corpus Separatum y que éste se haga realidad de hecho, $3^{\circ}$ que en caso de que la ONU no pudiese asumir ese control

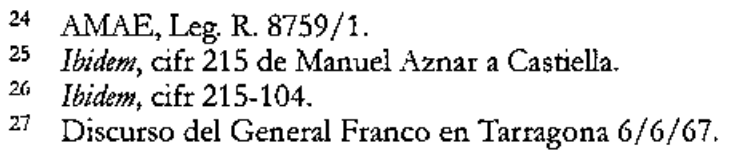

Hi.pania, LIX/2, núm. 202 (1999) 693-718 
sobre Jerusalén lo podrían tomar los cónsules de las potencias interesadas en el problema, es decir, España, Francia e Italia especialmente en la Ciudad Vieja y $4^{\circ}$, instar a estas potencias citadas a que gestionen cerca de los Gobiernos civilizados la ejecución de este plan como servicio a toda la humanidad ${ }^{28}$.

Esta comunicación de intenciones vaticanas es completada con una carta personal del propio Garrigues a Castiella en la que le da su propia visión del conflicto con tespecto a España.

"En primer lugar destaca el gran inconveniente que plantea nuestra acción en la zona, debido a la no existencia de relaciones diphlomáticas con Israels. Según Garrigues la actuación de Nasser es la de un loco privado de razón, totalmente intempestiva y de falta de cálculo pero también este fracaso habría que capitalizarlo scomo favorable a nuestros intereses, pues el desfondamiento total del mundo árabe y la derrota de Nasser, escribe Garrigues, constituye un gran ainso para las actuaciones independentistas de Marruecos en el Sábara español, que se hubieran visto en otro caso reforzadas por el triunfo árabe en el terreno militar y de la violencias. Apunta el embajador español el posible auge del Sionismo y las ventajas de los intereses petrolíferos que supondrá la victoria de Istael para Francia e Inglaterra, que tomarán la revancha de la derrota del $56^{2 \%}$.

El mismo día 7 la posición española en la ONU no prospera al no introducir el embajador argentino el texto sobre los Santos Lugares prometido al embajador Aznar debido a las presiones norteamericanas. El diplomático argentino suprimió el texto. «Me dice el embajador que a úlitima bora resolvió suprimir dicho párrafo pues le parecia que tal manifestación no guardaba coberencia con relación al alto el fuego. Discretamente be disentido de esta interpretación pero sin reiterar el disentimiento puesto que el asunto no conserva actualidad. Por abora el llavero que suele abrir el templo del Santo Sepulcro en vez de ser musulmán, será judio y los peregrinos serán recibidos por Israely no por Jordanian ${ }^{30}$.

Durante los dias en los que el conflicto adquiere mayor virulencia, es decir, los días 6,7,8 y 9 la diplomacia española sigue muy atenta a la evolución de los acontecimientos y su actividad se dirige hacia varios frentes como ya hemos indicado. El embajador español en Washington, Merry del Val, el mismo día 7 de junio informa a través de un telegrama a Castiella en que le expresa que:

«Los éxitos militares de Israel y la ruptura de relaciones diplomáticas de seis países árabes con EEUU ha envalentonado considerablemente a la influyente minoría judía de este país exaltada además por la presencia en Nueva York del ministro de relaciones exteriores de Istael, cuyas vibrantes declaraciones y proclamación de victoria han tenido repercusión en la opinión pública y la prensas. Dicha opinión, según el telegrama, pretendía que EEUU abandonase la no beligerancia y apoyase decididamente a Israel propugnando como límites definitivos del Estado la actual ocupación de los territorios incluída la ciudad de Jerusalén y los estrechos de Tiran y algún otro punto del Canal de Suez. En apoyo de estas demandas esta minoría judía anuncia para mañana una impor-

28 Ibidem, cifr 121 de Garrigues a Castiella.

29. AMAE, Leg. R. 8759/1. Carta de Garrigues a Castiella. 7/6/67.

30. Ibidem, cifr. $2237 / 6 / 67$.

Hilpsutia, LIX/2, núm. 202 (1999) 693-718 
tante manifestación frente a la Casa Blanca y del Congreso para hacer presión ante el Gobiemo y el Parlamento, dando la casualidad de que muchos organizadores e inspiradores que exigen mayor beligerancia de Israel son líderes de movimientos pacifistas de protesta contra la intervención norteamericana en Vietnam. Se anuncia igualmente una contramanifestación de la minoria árabe americana en representación de un millón de ciudadanos de origen árabess ${ }^{31}$.

El mismo día 7 de nuevo Merry del Val, horas más tarde sigue informando a Madrid de las reacciones del Gobierno norteamericano preocupado seriamente por las declaraciones del Ministro de Defensa de Israel, en el sentido de no abandonar ninguno de los territorios ocupados, inchúdo Jerusalén. El telegrama del embajador español es bien elocuente. «Estas declaraciones comprometen seriamente a los EEUU cuyo presidente ha afirmado categórica y reiteradamente en el curso de estos días que el Gobiemo mantiene firmes sus propósitos de mantener la integridad territorial nacional de las fronteras de todos los países sin excepción. Sin embargo, el Congreso y en especial la minotia republicana, sin duda influida por el senador judío Javits y con miras de conseguir voto y apoyo de los judíos norteamericanos en las próximas elecciones, parecen dispuestos a hacer presiones cerca del presidente para que no insista en oponerse a nuevas reivindicaciones territoriales $\mathrm{dc}$ Istaels ${ }^{32}$.

La cuestión se le ponía dificil por este lado al gobiemo de Madrid.

Durante los días 7, 9 y 12 el Consejo de Seguridad de la ONU adopta las resoluciones 234,235 y 236 . Fué Jordania el país que adoptó primero el alto el fuego. En los días 8 y 9 siguieron la actitud jordana, la RAU y Siria y un poco más tarde el Líbano.

E1 8 de junio el MAE emite una nota informativa basada sobre todo en el problema de los refugiados de Palestina acusando a Israel de crear la situación, «la verdad del caso - dice la nota - es que el ejército judio realizo metódicamente unas operaciones de exterminio total bumano en algunas aldeas árabes que crearon un ambiente de pánico que provocó su buidà.

La resolución del 12/48 la ONU adoptó en la misma que los refugiados debían de volver a sus hogares y ser indemnizados por Istael por el daño causado. La situación fué algo mitigada con el establecimiento de la U.N.R.W.A. organismo dedicado a atender las necesidades de los refugiados cuyo mantenimiento en gran parte corre a cargo de EEUU y en menor medida de Inglaterra. El gobierno español además - en la nota- acusa al resto de los países pues su recogida en los campamentos era una prueba a su favor y contra Istael. El gobierno español había ayudado a estos refugiados con el envio de aceite por valor de 2 millones de pesetas y en 1964 estuvo a punto de enviarles harina de trigo, lo cual no se concretó. España siempre votó en la ONU a favor de que se cumplietan las decisiones de la ONU de la vuelta de los refugiados a Palestina, incluso la última vez, en noviembre de $1966^{33}$.

31 'Ibidem, cifr. 413 de Merry del Val a Castiella.

32 Ibidem, cifr. 419.

33 Ibidem. Nota del MAE sobre refugiados palestinos $8 / 6 / 67$.

II.pquania, LIX/2, núm. 202 (1999) 693-718 
Por otra parte, en España se sigue muy de cerca el ptoblema de los Santos Lugares. El consejero de la embajada italiana en Madrid se dirige al MAE solicitando información sobre la posición española en torno a los mișmos, dada nuestra buena relación con los árabes.

En este asunto la embajada italiana esperaba lo mismo que la española, ¿cuál sería la actitud norteamericana?. Sin embargo, el Gobierno italiano actuaba bajo la dirección del Vaticano, «saqué la impresión -dice la nota- que la Santa Sede ha escogido a Italia como su peón de bregas y que Italia lo hacía con gusto para tomar iniciativas que le proporcionasen prestigio internacional ${ }^{34}$.

Sobre la mesa de Castiella se amontonan los informes de los embajadores españoles en los países árabes y las reacciones y manifestaciones contra las embajadas norteamericanas y en algunos del Norte de África, así como contra las propias sinagogas con algunos asesinatos ${ }^{35}$.

El cónsul español en Jerusalén en medio de las dificultades de la situación comunica el 13 de junio a Castiella que Italia y Francia actuaban por mantener el protagonismo sobre los Santos Lugares. Italia, como peón de brega de la Santa Sede, y Francia buscaría como siempre, escribe el cónsul, una política de prestigio poniéndose a la cabeza de los países interesados ${ }^{36}$.

Las quejas españolas en torno al desenlace de los hechos y de la forma que afectaron al Consulado español se resumen en una nota en la que se quejan del trato recibido por las fuerzas istalies un tanto violento, aunque estos se excusaron por el clima bélico y en cierta medida incontrolable, fueron las explicaciones dadas por el Gobierno judío de Jerusalén. Se queja el cónsul de la impotencia de contactar con el Gobierno israeli al no haber relaciones diplomáticas que sin embargo contrasta con el hecho patente de la existencia en España de un diplomático israelí que se hace pasar por agente de su Gobierno y contacta libremente con las autoridades españolas sin más problemas ${ }^{37}$.

\section{EL. FINAL DEL CONFLICTO. LA POSICION ESPAÑOLA EN LOS FOROS INTERNACIONALES}

Ya al inicio del conflicto el Gobierno español a instancias de los Gobiemos norteamericano y británico manifestó su posición. Estas consultas fueron hechas también a los demás países mediterráneos especialmente a Francia e Italia. Tanto Gran Bretaña como EEUU pretendían obtener el apoyo colectivo sobre la libertad de navegación por el Golfo de Akaba, bloqueado por Egipto con el apoyo de los demas países árabes. El Gobiemo español se abstuvo de tomar

\footnotetext{
34 Ibidem. Nota para el ministro 13/6/67.

35 Ibidem, cifr. 177 del embajador en Rabat a Castiella 12/6/67. $13 / 6 / 67$.

Ibidem, nota para el ministro y comunicación telefónica con el Cónsul en Jerusalén

37 Ibidem, pág. 2. Se trata de Jonathan Prato, diplomático israelí de origen sefardita. Ver A. Marquina y G. Ospina op. cit., pág. 307.
}

Higrania, LIX/2, núm 202 (1999) 693-718 
ninguna medida al respecto aduciendo que no se había hecho suya otra análoga de $1957^{38}$.

El mismo día 6 el propio General Franco había dicho en el ya citado discurso de Tarragona que uante el conflicto que el Oriente del Mediterráneo padece nosotros bemos de afirmar nuestros propósitos de que los Santos Lugares queden libres de toda perturbación y de toda guerra y que una paz justa y digna pueda llegar a aquellos pueblos amigoss ${ }^{39}$. Por otra parte, la actitud del Gobierno español ante el conflicto fue tratada en los Consejos de Ministros de los días 16 y 23 de junio respectivamente. En éste último se aprueba la ayuda española (iniciada anteriormente con cáracter de urgencia a las víctimas de la Guerra) se acordó facilitar una ayuda especial a los estudiantes árabes cuyas familias se hubieran visto desplazadas o hubiesen sufrido graves consecuencias a causa del conflicto. En otro frente diplomático el Gobierno español asume la protección de los intereses norteamericanos en la RAU y Mauritania, a requerimiento del Departamento de Estado norteamericano y en parte como una contribución de España para no desairar a las presiones norteamericanas. En las instrucciones dadas a los embajadotes se especificaba que el principal motivo de la iniciativa española era en la medida de lo posible defender los intereses mauritanos y egipcios, sirviendo al mismo tiempo de cauce de diálogo con los Estados Unidos haciendo todo lo posible porque estos intentaran el establecimiento de relaciones con los árabes. España intentaba jugar estas bazas de cara a mantener su eclectismo en algunos puntos, en su interés, respecto especialmente de Washington y basando la protección en la especial posición de España hacia esos países islámicos y de los beneficios que de ellos se derivarían ${ }^{40}$.

$\mathrm{Ya}$ antes de iniciarse los debates en la ONU sobre el futuro de los territorios ocupados por Israel durante la Guerra, España diseña su estrategia de acuerdo principalmente con los árabes y los países hispanoamericanos.

Previamente la RAU pide al Gobierno español a través del embajador español en El Cairo, que ejerza su influencia cerca del bloque hispanoamericano y otros países amigos en el sentido de que apoyen la propuesta de Resolución Yugoslava como la más conveniente a los intereses árabes. Las directrices españolas sobre este asunto fueron dadas por el propio General Franco y que consistían en: la vuelta de los ejércitos istaelíes a sus viejas fronteras, inspección de la ONU en los territorios ocupados por Israel, garantía de navegación para este país por el Golfo de Akaba y garantía de libre navegación por el Canal de Suez, que continuaría bajo administración egipcia ${ }^{41}$.

La diplomacia española sondea a los países árabes sobre estas propuestas y encuentra una falta de unión en cuanto a sus objetivos y pretensiones. Por ejemplo aceptan el plan yugoslavo la RAU, Jordania, Libia, Túnez y Sudán. Siria se opone al plan Tito y exige la retirada israelí previa. El resto mantienen pos-

\footnotetext{
38 AMAE, Leg. R. 8759/1. Memorandum del MAE sobre el conflicto.

39 Discurso del General Franco 6/6/67.

40 AMAE, Leg. R. 8759/1.

41 AMAE, Leg. R. 8759/1 Instrucciones del General Franco al Ministro Castiella.
} 
turas ambiguas y poco claras. Ante esta situación, España decide respaldar el plan yugoslavo.

En las sesiones del Consejo de Seguridad se había adoptado por un voto unánime el 14 de junio, una resolución patrocinada por Argentina, Brasil y Etiopía, referida a la protección de civiles y otra referida al problema de los refugiados y víctimas del conflicto. Sin embargo el órgano supremo no pudo llegar a ningún acuerdo sobre el problema de fondo, obteniendo únicamente a través de una comisión de supervisión de la tregua el envío de observadores al Canal de Suez. La convocatoria de una Asamblea General extraordinaria a petición de la Unión Soviética para resolver tan grave asunto fue apoyada por España, después de haber hecho toda clase de gestiones cerca del presidente y demás organismos de las Naciones Unidas haciendo ver su preocupación por la no observación del alto el fuego, haciendo hincapié, en que fueran puestas en práctica las recomendaciones del Consejo de Seguridad ${ }^{42}$.

A partir del día 19 se inician en la Asamblea extraordinaria una serie de debates en los que se perciben el enfrentarniento de las tesis norteamericana y soviética. Mientras que la primera propugnaba el condicionamiento de la retirada de las tropas istaelíes al cese de la beligetancia, y apoyaba el sistema de discusiones árabes-israelies con la asistencía eventual de una $3^{3}$ potencia, la soviética proponía la retirada inmediata e incondicional a las líneas del armisticio de 1949 y condena de Istael como país agresor. Los árabes techazaron de plano la propuesta notteamericana mientras que los israelíes propugnaban las discusiones directas con los árabes. En medio de estas posiciones casi irreconciliables patrocinadas por las dos grandes potencias se iban gestando las posiciones de los demás países. Fundamentalmente fueron tres las posiciones que lograron ser discutidas y en torno a las cuales se gestó la posición definitiva. $\mathrm{La} \mathrm{1}^{\mathrm{a}}$, $\mathrm{CO}-$ nocida como Plan Yugoslavo, apoyado por otros 13 países, que defendía la retirada total de Israel y eludía la condena del mismo como país agresor. $\mathrm{La} 2^{2}$ mucho más ecléctica, propuesta por los países hispanoamericanos apoyados por EEUU que pedía la retirada de las fuerzas de ocupación sin fijar límite de tiempo y abogaba por una solución negociada del conflicto y además propugnaba la libre navegación por aguas internacionales, una solución del problema de los refugiados y asegurar la integridad territorial de todos los países del Oriente Medio. Y la $3^{\mathrm{a}}$ y última, Albania que condenaba a Isarel y a los países occidentales ${ }^{43}$.

Ante este panorama, el jefe de la Misión diplomática española, Manuel Aznar, recibió instrucciones de Castiella para que se mantuviera en contacto con los representantes de Argentina y Brasil a fin de llegar a una resolución en el que se reconociesen tanto los derechos árabes como el principio fundamental de que no se podía admitir un premio a la agresión, por el grave precedente internacional. Pero aparte de estas gestiones el gobierno sirio presionaba al go-

42 Ibidem. Informe del MAE sobre la posición española en la ONU 20/9/67.

43 Ibidem, pág. 2.

Hijpania, LIX/2, nún. 202 (1999) 693-718 
bierno español a través del embajador en Damasco, en el sentido de que Espana interviniera ante las partes amigas y especialmente hispanoameticanos para que votaran a favor de la restitución del territorio árabe ocupado por Israel y que el Estado hebreo obtuviera una condena como agresor ${ }^{44}$.

Por otro lado, la posición de la Santa Sede era más bien de un eclectismo práctico; ante los países católicos mantenía y exhibía sus propuestas sobre la internacionalización de Jerusalén, cuestión ésta que siempre mantenía como objetivo a conseguir aduciendo siempre como testimonios las innumerables encíclicas de los Papas, especialmente de Pío XlI, en la que reclamaban un status especial para Jerusalén.

L'Observatore del 9 de Junio hacía referencia a las siguientes: Auspicia Quedam, 1/5/48, Redemptoris Nostri, 15/4/49, Solemnibus Documentis 8/12/49. Sin embargo haciendo gala de un pragmatismo político de hecho apoya la situación del Status Quo actual aún sin reconocer al Estado de Istael ${ }^{45}$.

E1 20 de Junio la oficina de información diplomática del MAE recibe una comunicación de la Agencia France Press cuyo texto es bien elocuente, refiriéndose a Jerusalén. "La susceptibilidad sigue siendo muy viva como lo ban demostrado estos dias las reacciones diplomáticas provocadas por las palabras del P. Costantin Kose, general de los Franciscanos, quien en el curso de una conferencia dió la impresión de que la Iglesia se acomodaría a la situación de becho creada en Jerusalénn.

La Santa Sede se preocupará además de la suerte de los refugiados sobre los que ya Pío XII había pedido un trato justo y una situación duradera ${ }^{46}$.

Tan sólo cuatro días más tarde el observador del Vaticano en la ONU, Monseñor Alberto Giovanesti, hizo entrega de una nota a todas las delegaciones, en las que se fijaba la posición de la Santa Sede, basada en la internacionalización, cuestión ésta que tenía como finalidad tratar de interponerse entre los proyectos soviético y norteamericano. La nota coge a contrapelo a los Gobiernos del bloque hispanoamericano que ya habian iniciado el traslado de sus capitales a Jerusalén y no querían contravenir las directrices de la Santa Sede. La cuestión quedó tesuelta según el telegrama al término de una reunión del ministro de Asuntos Exteriores Israelí Abba Eblan, con todas las delegaciones hispanoamericanas a las que Israel dió garantías de libertad de acceso a los Santos Lugares. Sin embargo, eludió cualquier referencia a cambiar su posición en torno a la internacionalización, a la que se oponía. Esta era sin duda una politica de hechos consumados que la Santa Sede y el bloque latino aceptaron como mal menor, sin duda, bajo la influencia norteamericana ${ }^{47}$.

E1 4 de Julio se procedió a la votación de los proyectos. El presentado por los hispanoamericanos aunque obtuvo muchos votos no alcanzó los $2 / 3$ necesarios. España no lo apoyó, se abstuvo y tampoco se atrevió a votar en contra, en cierta medida para contemporizar con ellos ya que había mantenido inten-

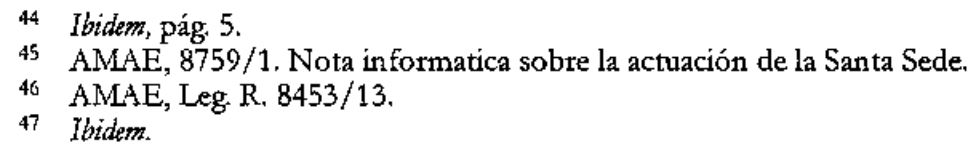


sos contactos y no quería exponerse a perder totalmente el apoyo norteamericano que en aquellos momentos también le era importante. Sin embargo, siguiendo intrucciones de Madrid votó a favor, sin duda presionado por los árabes, del proyecto yugoslavo al lado de la Unión Soviética, países africanos, Francia, Grecia y Turquía entre otros ${ }^{48}$.

Ninguno de los proyectos sin embargo alcanzó el Quorum necesario. Como consecuencia de este fracaso la delegación española aparte de la actividad desplegada especialmente cerca de los países hispanoamericanos elaboró de acuerdo con éstos un anteproyecto de Resolución en el que en síntesis proponía: $1^{\circ}$ instar a Israel a que retire inmediatamente sus fuerzas de todos los territorios ocupados, $2^{\circ}$ instar a las partes interesadas a no recurrir a la fuerza militar, y reafirmar el derecho de cada parte a su seguridad y verse libre del temor de ataque por las fuerzas armadas de la otra parte, $3^{\circ}$ petición al Consejo de Seguridad, al estudio de fórmulas pacíficas para resolver el conflicto, $4^{\circ}$ el nombramiento de un representante del Secretario General que mantenga los contactos con las partes para la solución de los problemas de la Región, $5^{\circ}$ reitera sobre todas las recomendaciones anteriores para establecer un régimen internacional para Jerusalén, cuyas modalidades serán fijadas por la Asamblea General en su XXII período de sesiones. Estas gestiones españolas fueron aprobadas desde Madrid con una condición sine qua non, de que siempre contasen con la explícita conformidad de los árabes ${ }^{49}$.

Es evidente que la intensa actividad diplomática española se orientó fundamentalmente como ya se hizo en 1948-49 a tratar de captar los votos hispanoamericanos de apoyo a los árabes, a cambio éstos permitirian la internacionalización de Jerusalén, que eta el objetivo del Gobierno de Madrid. Esta actividad diplomática se encontró con la oposición norteamericana, a la que desagradó la politica desarrollada por la Delegación española creando situaciones de tensión a finales de junio y primeros de julio de ese mismo año con el gobierno de Washington. En efecto la embajada norteamericana en Madrid presentó un memorandum en el que el Gobierno norteamericano se lamentaba de la actividad diplomática española en la ONU en torno al anteproyecto arriba reseñado y a otros anteriores y pedía que el Gobierno español evitase todo acto tendente a facilitar la aprobación de una fórmula de compromiso ${ }^{50}$.

Es indudable que esta posición norteameticana colocaba literalmente contra las cuerdas a la diplomacia española en sus intentos de mantener sus objetivos de actuación sobre los Santos Lugares. Pocos días más tarde, el 11 de julio, y previo Consejo de Ministros el Gobierno español matizó a la embajada norteamericana su actuación, siempre eliminando cualquier teferencia al problema de la internacionalización de los Santos Lugares, concretándolo en las siguientes propuestas: $1^{\circ}$ España actúa en función de su lealtad a los países átabes. $2^{\circ} \mathrm{La}$ política de EEUU hacia el Mundo árabe es discutible, pues con-

\footnotetext{
48 Ibidem, informe MAE pág 6 y 7.

49. Ibidem, pág. 7 .

50 Ibidem, pág. 8.
}

Hispania, LIX/2, núm. 202 (1999) 693-718 
siste en dividir o intentar reestructurar a su conveniencia alrededor de un cuerpo extraño. $3^{\circ} \mathrm{La}$ iniciativa española no es sino un gesto de buena voluntad tendente a encontrar una solución que deje abierta la posibilidad de llegar a una solución de compromiso y a una paz digna y justa en Oriente Medio.

E1 12 de julio se cursan instrucciones a la Delegación española en la ONU en el sentido de que España seguiría fiel en la amistad con los países átabes y por tanto la delegación española habría de mantener lo hecho hasta ahora en relación con el anteproyecto y habría que apoyarlo si llegara a ser presentado. Sin embargo. España tuvo que doblegarse ante las presiones norteamericanas que a su vez presionan a los países hispanoamericanos incorporándoles a su proyecto y estos abandonan a la posición española hasta acabar boicoteándola. Este factor influyó de una manera decisiva en la actitud posterior de estos Gobiernos que se vieron obligados a ceder ante la fuerte presión norteamericana. Por otta parte, también contribuyeron a determinar esta postura de retraimiento la influencia de las comunidades judías en esos países y la intervención de la RAU en la conferencia tricontinental de La Habana apoyando los movimientos sociales de carácter comunista en Hispanoamérica, que indudablernente fueton bazas que el Gobierno norteamericano jugó en su favor. Aunque Israel no consigue unificar administrativamente Jerusalén y los átabes consiguen el aumento de ayuda a los refugiados. Las sucesivas reuniones y debates no consiguen resolver el problema. La propuesta de Pakistán en torno a la oposición de Israel de unificar administrativamente Jerusalén acaba triunfando. Cuestión a la que hay que añadir la propuesta sueca de aumentar la ayuda a los refugiados. La cuestión de fondo continuaba sin resolverse, logrando éxitos parciales tales como que el embajador suizo Telman elaborase sobre el terreno un informe en relación con el cumplimiento de las resoluciones adoptadas. Al final, el 18 de septiembre la Asamblea General logra introducir en los debates como asunto de alta prioridad la cuestión del Oriente Medio, adhiriéndose a la propuesta Israel, que anteriormente la había rehusado ${ }^{51}$.

\section{ESPAÑA Y LA EVACUACION DE LOS JUDÍOS DURANTE EL CONFLICTO}

La política exterior española en aquellos momentos consigue un cierto beneplácito de los países árabes y por otra parte no llegó a un rechazo total de EEUU, a los que tiene que hacer contrapartidas, tales como la protección de sus intereses en la RAU y Mauritania y consigue además que el bloque hispanoamericano no apoye las iniciativas españolas. Sin embargo toma la iniciativa en un asunto que le crearía buena imagen exterior en EEUU y muy especialmente dentro de las influyentes comunidades judias norteamericanas, como fué la evacuación de muchos judíos de los países árabes, en perfecta sintonía con la administración Johnson. Es evidente que este asunto fue una baza importante para no perder el apoyo de los EEUU en el campo internacional.

51 Ibidem, págs. 8 y 9. 
Durante el conflicto y en fechas inmediatamente posteriores, las comunidades judías instaladas en estos países, especialmente en Egipto donde residian las más numerosas, sufrieron como consecuencia del clima creado continuas extorsiones, encarcelamientos, confiscaciones de sus bienes por parte de los respectivos gobiernos, muchos de estos judios eran de origen sefardita. Ante esta situación y a la vista de otros precedentes muy cercanos, como la crisis de Suez en la que España intervino cerca de estos gobiernos árabes, dada la tradicional amistad con los mismos, consiguió paliar la situación angustiosa de muchos de ellos, logrando incluso la evacuación de muchos de estos judios. Varios organismos internacionales se dirigen al Gobierno español para que haga uso de sus buenos oficios ante los gobiernos árabes, en especial el de Egipto, con la finalidad de paliar en lo posible su situación. Entre estos organismos hay que destacar: El Comité judio americano, el representante norteamericano en la Comisión de Derechos Humanos, la Comunidad Sefardita de Chicago, el alto comisionado de las Naciones Unidas para refugiados y la Cruz Roja Internacional.

El Ministro Castiella el 10 de Junio cursa instrucciones muy reservadas a los embajadores españoles en Egipto, Libia, Marruecos y otros paises árabes «en el sentido de que de acuerdo con las autoridades locales y por todos los medios a su disposición, extiendan la proteción a todos los miembros de las comunidades judias, sefarditas o no, que se encontraran en situación peligrosa y que reclamaran la asistencia de nuestras misiones", se añadía que si se producian situaciones en las que las autoridades locales vinietan a desear la ayuda de alguna potencia para la repatriación de dichas comunidades habrian de darse las facilidades necesarias en cuanto a documentación para proceder a las correspondientes evacuaciones. Los representantes españoles actuarian en este sentido siguiendo la línea de conducta tradicional de nuestro país ${ }^{52}$.

Bajo este clima y con estas orientaciones se produce una gtan actividad diplomática con resultados muy positivos especialmente en Egipto, al frente de cuya embajada se encontraba D. Angel Sagaz que consigue la liberación de prisión de muchos de ellos y su repatr ación a otros países y también a España, hechos estos que no habían conseguido organismos internacionales como la Cruz Roja o el Departamento de Estado Norteamericano.

E1 24 de junio de ese año se consigue la evacuación de ocho judios y sus familias que el propio Sagaz comunica en un telegrama reservado a Castiella en el que pormenoriza sus nombres: «Ayer embarcaron en el Barco Benicasim con destino a Barcelona ocho españoles sefarditas, tres de ellos liberados de prisión. Ninguno de ellos tiene medios y desde su llegada babrá que ocuparse de mantenimiento y ulterior destinon.

Esta operación estaba combinada en España con la ayuda de las comunidades judías, especialmente de Madrid cuyo presidente entonces era el Sr. Max Mazin. La misión era arriesgada como se pone de manifiesto en carta dirigida al mismo por el presidente de la comunidad judía de El Cairo el 18 de Agosto

52 AMAE, Leg. R 7599/1, telegrama de Castiella a Sagaz. I. A. LISBon^ op. cit. págs. 203211.

Hiipania, LIX/2, núm. 202 (1999) 693-718 
en la cual le manifiesta que «comunique al Gobierno español el testimonio de su vivo reconocimiento a la eficaz intervención del embajador de España en El Cairo» ${ }^{53}$.

El propio Sagaz relata a Castiella las condiciones en las que tuvo que llevar a cabo dicha operación. El día 19 en otra comunicación reservada Sagaz confirma la salida de los 27 judíos y las dificultades que tuvo que vencer y la situación de enfermedad grave de Jaime Sasson Levi que habria sido enviado a Paris donde le espera un hermano y donde debe de sufrir una inminente operacion quirúrgica.

$\mathrm{La}$ mayor parte de estos judios eran pequeños artesanos empleados de casas comerciales. Sagaz apunta a Castiella que han sido despojados de todo cuanto poseen, tras verse obligados a vender de mala manera sus escasas propiedades para satisfacer las exigencias del fisco, especialmente duro con ellas. Las gestiones de la embajada de España fueron mucho más eficaces que las de otros organismos intetnacionales. «Debo señalar que ni los franceses ni los italianos ban conseguido aún obtener la liberación de aquellos apátridas casados con franceses o italianos, lo que esta embajada obtuvo bace tiempos ${ }^{54}$.

«La Cruz Roja tampoco puede bacer nada por ellos y cuando reciben alguna petición discretamente le sugieren a la embajada de España, que es la única que puede bacer algor ${ }^{55}$.

El impacto causado por el éxito de las gestiones del embajador español y ante la situación difícil que atraviesa la comunidad judía en El Cairo, ésta decide dirigirse directamente a Angel Sagaz con la propuesta de utilizar los servicios del mismo para transferir a España las reliquias, libros sagrados y objetos de arte para su salvaguarda.

E1 26 de Agosto, Sagaz (a través de una comunicación muy reservada) comunica a Castiella esta operación: she recibido con la elemental discreción la visita del presidente de la comunidad judia de El Cairo, Sr Ascher y el secretario de la misma... me dijeron que el objeto principal de su visita era expresarme el agradecimiento más profundo de la comunidad hebrea de Egipto por la extraordinaria labor humanitaria que España estaba llevando a cabo y me rogaban - escribe Sagaz- que esta gratitud fuese trasmitida al Gobierno español y a S.E el Jefe del Estado, me dijeron una vez más que el corazón magnánimo del Generalísimo Franco ha ayudado a salvar judios perseguidos como lo hizo en tantos países en la Segunda Guerra Mundialy.

La segunda cuestión la expresa así el propio Sagaz: «me expusieron el deseo de ofrecerme para su conservación en esta embajada o su eventual traslado a España una serie de pergaminos $y$ libros, algunos de ellos del siglo $X y$ que se hallaban en las viejas sinagogas de El Cairo y que al estar cerradas y abandonadas se perderán».

La respuesta de Sagaz es negativa debido a que estas piezas históticas estaban catalogadas por el Gobierno de la RAU y que el Gobierno español se vería entonces inmerso en un problema de evasión del patrimonio artístico. Aún así la comunidad judia egipcia entrega algunas piezas a la embajada española: «.... y

53 Ibidem, carta del presidente de la comunidad judia de El Cairo a Max Mazin.

54 AMAE, Leg. R 7591/1, carta reservada de SAGAZ a CASTiELLA con lista de judíos.

55 Ibidem, carta de SAGAZ a CASTIELLA 26/8/67.

Hispanta, LIX/2, núm. 202 (1999) 693-718 
que quisieron ofrecer para que se conserven en la comunidad judia de Madrid. Me añadieron que en el futuro algunas de estas piezas desearian exbibirlas en la Sinagoga de Toledon 56 .

El propio Sagaz y el Gobierno español valoran positivamente esta posición de los judíos egipcios: «creo que es de agradecer por nuestra parte que se confie en España la custodia de aquellos objetos sagrados pertenecientes a sinagogas cerradas, es el único país que por razones evidentes puede y quiere hacerlon.

Mientras se producía este hecho, la labor de rescate y evacuación sigue adelante y las gestiones de la embajada española prosiguen en ese sentido ${ }^{57}$.

El mismo día 26 Sagaz comienza la gestión por la liberación de 29 detenidos que junto a sus farnilias se componen de 100 personas; el destino final de estos judíos era principalmente Estados Unidos y Canadá, una vez llegados a España. "Van sin medios -escribe Sagaz-para efectuar sus primeros gastos y tendrán que ocuparse de ellos en forma organizada los servicios sociales españoles y las comunidades judias de Madrid y Barcelonas.

Dado el clima de guerra y la posición proclive del Gobierno español hacia los países árabes, las operaciones se llevan a cabo con la máxima reserva. «Excuso decir, lo que interesa es que la máxima discreción presida toda su llegada y estancia en Españay. En el mismo documento se adjunta la lista de los nombres de cabeza de familias detenidas.

El éxito de estas gestiones españolas producen un efecto inmediato en las organizaciones internacionales que se dirigen al Gobierno español como canal de contacto y salvación.

E1 29 de agosto de ese mismo año el embajador de España en Washington, Marqués Merry del Val, recibe un memorandum de la American Jewish Comitee firmada por Andre Boly, en la que le transmite la lista de judíos presos en Egipto agradeciendo al mismo tiempo las gestiones llevadas a cabo por el Gobierno español. En dichos documentos se refleja la situación angustiosa en la que se encontraban muchos de estos judíos, algunos de ellos gravemente enfermos y con el agravante de no saber su situación real en aquellos momentos, si estaban liberados o bien desaparecidos. Ante la falta de datos fidedignos, se dirigen al Gobierno español a través de la embajada española en Washington para saber cuál era la situación real, consultando el caso concreto del judío $\mathrm{Da}$ vid Abufalia y su familia e intentar conseguir su liberación y evacuación. Las pretensiones además de esta organización tienen mayor alcance. «Nuestra oficina de Paris, dice el memotandum, tiene informaciones de que un número de judios sirios quiere abandonar el Lubano en el transcurso del mes de septiembren, pero ante la imposibilidad de conseguir pasaporte, pide al gobierno español que curse instrucciones a su representantés diplomáticos, tanto en Siria como en el Libano, para que del mismo modo que se dieron intrucciones a estos mismos representantes en otros países árabes, se haga lo mismo, cuestión ésta que el gobierno español había comunicado a la propia American Jewish Commitee el 22 de junio. En

56 AMAE, Leg R 7599/1, comunicación reservada de SAGAZ a CASTIEILA.

57 Ibidem.

Higpania, LIX/2, núm. 202 (1999) 693-718 
aquellas fechas fueron realizadas las gestiones por el Gobierno español. En el caso del Gobierno libanés, que era considerablemente más moderado que los otros, con la intención de proveer de pasaportes necesarios, sería menos difícil y menos reducido en número que en otros gobiernos árabes en los que los representantes del gobierno español han sido activos ${ }^{58}$.

Tan sólo dos días más tarde, el 31 de julio el delegado internacional de la Cruz Roja Internacional se traslada desde Ginebra y se entrevista con el embajador español. La propuesta de Vust es canalizar toda la ayuda humanitaria a través de la Embajada Española, incluso ante las propias demandas del Departamento de Estado norteamericano ${ }^{59}$.

Mientras tanto, los contactos y las gestiones siguen entre el Gobierno español, las organizaciones judías y el Gobierno norteamericano. E1 8 de septiembre el embajador español en Washington entrega la lista completa de los 27 repatriados judíos a España al Sr Lewin dirigente del American Jewish Commitee que a su vez entrega la lista de otro número de judíos detenidos en El Cairo y Alejandria ${ }^{60}$.

De nuevo Sagaz el día 9 de septiembre comunica a Castiella que otro grupo de evacuados partía para España: «Ayer salieron en un barca español de Benicasim veinte evacuados judios en cumplimiento de circular numero 128 de junio pasados ${ }^{61}$.

Dutante esta época se va consiguiendo, pues, la evacuación de una gran parte de la comunidad judía. Al menos tenemos constancia documental de cetca de cuarenta personas con sus respectivas familias que en principio llega a España, siendo atendidos por servicios sociales españoles y las comunidades judías de Madrid y Barcelona.

El hecho tuvo gran impacto en las organizaciones judías de casi todo el mundo. E1 15 de Septiembre el presidente de la comunidad de Madrid Max Mazin, recibe una carta de la American Jewish Commitee en la cual le comunica que aparte de agradecer al Gobierno su labor humanitaria se deberia hacer pública esta labor y su agradecimiento ${ }^{62}$.

\section{MODO DE EPÍLOGO}

Hemos abordado en las páginas precedentes la visión española en torno al conflicto conocido como la Guerra de los 6 días. Ahora bien, la pregunta que se suscita es la siguiente: qué interés tendría para España este conflicto. Aparentemente ninguno. Sin embargo dada la especial situación española en torno a ambos contendientes su posición no era ni mucho menos indiferente. $28 / 8 / 67$

58 Ibidem, carta del presidente de la American Jewish Commite al embajador Merry del Val

59 AMAE, Leg. R 7599/1.

60 Ibidem, cift 328 de Merry del Val a CASTIELLA 8/9/63.

61 Ibidem, carta de SAGAZZ a CASTIELLA

62 Ibidem, carta dirigida a MAz MAZiN por la American Jewish Commite.

Hipgnia, LIX/2, núm. 202 (1999) 693-718 
El propio régimen del General Franco al inicio del conflicto en 1948 intentó por todos los medios ser reconocido por el estado de Israel, tratando así de alejar la imagen de un régimen vinculado al fascismo italiano y al nazismo alemán utilizando como arma propagandista la salvación de miles de judios en la $2^{a}$ Guerra Mundial. El recién creado estado hebreo no comunicó siquiera al Gobierno español la constitución como tal estado en un gesto claro de antagonismo.

Sin embargo el régimen del General Franco pretendía ya entonces un protagonismo en el conflicto del Oriente Medio haciendo valer sus derechos históricos sobre los Santos Lugares y movilizando a tal efecto su influencia sobre los países hispanoamericanos y árabes. En cuanto a los primetos se intentaba que apoyasen en los Foros internacionales la causa árabe y vetasen al estado de Istael; en contrapartida estos apoyarían las pretensiones españolas de convertir Jerusalén en Ciudad internacional regida por un "Corpus Separatum» en el cual los Santos Lugates estatían controlados por las potencias católicas: Italia, Francia, España y Bélgica. Esta operación fracasó debido en gran parte a la falta de apoyo norteamericano y británico y a la política ambigua del Vaticano.

El cuadro anteriormente descrito vuelve a repetirse casi igual. La decidida política proárabe del entonces ministro Castiella buscaba también, como entonces Artajo, un protagonismo en su intervención en el problema de los Santos Lugares, cuestión que fracasa también por las mismas causas. A esta situación hay que añadirle algunas variables nuevas, como son la presión norteamericana sobre España por la política proárabe desarrollada y que se extiende también a los países hispanoamericanos. Sin embargo, el Gobierno español logra una buena imagen exterior con la operación de la repatriación y protección de judios en varios países árabes, especialmente de Egipto y del Líbano.

\section{ABREVIATURAS}

AMAE: Archivo Ministerio Asuntos Exteriores.

MAE: Ministerio de Asuntos Exteriores.

ONU: Organización de Naciones Unidas.

Leg. R: Legajo renovado.

Cifr. Telegrama cifrado.

Hippania, LIX/2, núm. 202 (1999) 693-718 